Vol. 3, No. 2, Juli 2019, 51-56

Available Online at https://ejournal.warmadewa.ac.id/index.php/kulturistik DOI: dx.doi.org/10.22225/kulturistik.3.2.1193

\title{
THE TRANSLATION OF POLITENESS IN SUPERNOVA: KSATRIA, PUTRI \& BINTANG JATUH INTO SUPERNOVA: THE KNIGHT, THE PRINCESS AND -THE FALLING STAR
}

\author{
Ni Putu Santi Ashari Rahayu \\ Universitas Udayana \\ santiashari11@gmail.com \\ I Gusti Ayu Gde Sosiowati \\ Universitas Udayana \\ sosiowati@yahoo.com \\ I Nyoman Arya Wibawa \\ Universitas Udayana \\ inyoman.aryawibawa@gmail.com
}

\begin{abstract}
This study aims to find out and analyze types of politeness strategy expressed by the characters in the novel, to find out the procedures of translation applied to translate the politeness strategy applied by the characters in the novel and also to identify factors that affect the translation of politeness differences in the novel entitled Supernova: Ksatria, Putri \& Bintang Jatuh translated into English. The data of this study was taken from a novel entitled Supernova: Ksatria, Putri \& Bintang Jatuh and its translation into English. This study is limited into only analyzing the politeness strategy expressed by the characters in the novel and also analyzing translation procedures applied in translating politeness in the source language to the target language. This study used a qualitative method means the data are collected by observation and note taking process. The theories applied in this study such as from Brown \& Levinson (1978) to analyze the politeness strategy, the procedures of translation theory proposed by Vinay and Dalbernet (in Hatim and Munday (2004), and to analyze factors that affect the translation of politeness in the novel, theory based on the ideas of the possibility in translation by Cohen (1985) which is also related to Rand (1966) philosophy of objectivism, objective reality \& conceptual equivalence, and anthropological linguistics by Foley (1997) are applied. The result of this study showed that the type of politeness which mostly applied in the dialogue is positive politeness, the politeness strategies in the dialogue of the novel presented in oblique translation, and the politeness differences applied in the novel (Bahasa Indonesia and English version) held a very important role in forming and delivering the right messages that wanted to convey by the author to target language. The translator who also played an important role in bridging the message also consider context, and more importantly culture in which belong to the expected target readers.
\end{abstract}

Keywords: translation, politeness, translatability 
Vol. 3, No. 2, Juli 2019, 52

Available Online at https://ejournal.warmadewa.ac.id/index.php/kulturistik DOI: dx.doi.org/10.22225/kulturistik.3.2.1193

\section{INTRODUCTION}

Translation as a bridge between languages has many different aims. The main aim of translation is to serve the cross-cultural bilingual communication among people. According to Larson (1998) translation consists of transferring the meaning of the source language into the receptor language. In translating activity, a translator plays a very central role in keeping the message from a source language to another language. Furthermore, a translator must also be able to adjust the structure and the meaning in the two languages due to the two different linguistic systems and cultures. According to Larson, translation consists of transferring the meaning of the source language into the receptor language (Larson, 1998). The transfer of meaning between two languages enable people to stay connected to each other without any language barrier. It is possible because, according to Margono translation involves three aspects namely science (part of comparative linguistics), knowledge (about language and outside world) and art (in using efficient and effective words) (Margono, 1999). Those three aspects are related one another that enables transfer of meaning between languages. There are competencies that should be possessed by translator, such as language competence, textual competence, subject competence, cultural competence, and transfer competence (Neubert, 2000). The social backgrounds of the characters in the novel become very good issue, and interesting to discuss in this study especially by using politeness theory. Translating this kind of work can be challenging for translator if he or she does not understand context. The translator must also be able to bridge a message to be conveyed by the author.

\section{METHOD}

The data were taken from novel entitled Supernova: Ksatria, Putri \& Bintang Jatuh written by Dewi Lestari in 2001. The novel was translated into English by Aveling the translated version entitled Supernova: the Knight, the Princess and the Falling Star (Aveling, 2011). The novel was chosen to be the data source for this study because it is related very much to the present study which will focus on discussing politeness strategies in translation. Different social background of characters are presented interestingly by Lestari in the novel, makes the novel very interesting to be discussed. As an Indonesian writer, Lestari come up with a very brief story of a homo-sexual couple, a sex worker- model, and an unfaithful couple in an eastern country who the people still believe that those kinds of things are taboo (Lestari, 2001). Besides, the translator is an Australian who has a very different background of society with Indonesian people. This becomes a huge challenge for the translator especially to translate the politeness used in the novel to become properly acceptable for the target readers.

\section{DISCUSSION}

The analysis of the types of politeness, how the politeness express by the characters and how the politeness difference affect the result of translation is presented as below: 
Vol. 3, No. 2, Juli 2019, 53

Available Online at https://ejournal.warmadewa.ac.id/index.php/kulturistik DOI: dx.doi.org/10.22225/kulturistik.3.2.1193

Table 1. Analysis of Types of Politeness Applied in the Novel entitled Supernova: Ksatria, Putri \& Bintang Jatuh into English

\begin{tabular}{|c|c|c|}
\hline $\begin{array}{l}\text { Name of } \\
\text { Charac- } \\
\text { ter }\end{array}$ & Source Language & Target Language \\
\hline Reuben & $\begin{array}{l}\text { Saya nggak mengerti. Kok ada orang- } \\
\text { orang yang malah tidur? Ini adalah mo- } \\
\text { men yang nggak ada duanya. A mile- } \\
\text { stone. (1.3) }\end{array}$ & $\begin{array}{l}\text { How can those guys sleep? } \\
\text { There has never been a mo- } \\
\text { ment like this before. It's } \\
\text { whole new beginning. (1.12) }\end{array}$ \\
\hline Types of & Off record strategy & Off record strategy \\
\hline Politeness & Strategy 6: Tautologies & Strategy 5: Overstate \\
\hline
\end{tabular}

In data 4-1, Reuben used off record strategy in his utterance but the strategy used in the translated version is different. In Bahasa Indonesia Reuben used strategy 6: Tautologies while in English he used strategy 5: Overstate.

By using strategy 6: Tautologies, speaker wanted to encourage hearer to look for informative interpretation of the non-informative utterances (Brown \& Levinson:1978). This strategy serves the situation in which speaker try not to impose directly to the interlocutor by removing themselves from any imposition. According to Brown and Levinson (1987) the utterances in off record are essentially indirect uses of language in which speaker says something that is either more general or actually different what ones means. Off record strategy is divided into fifteen strategies (Brown \& Levinson: 1978).

In data 4-1 (Bahasa Indonesia), Reuben tried to inform Dimas and especially others at that party that they should not waste their time as they gave up and slept. Reuben said "A milestone" which is a non-informative utterance as a hint for all of them that the moment they experienced is a once in a life time moment which will gave them happiness and joy for the rest of the night.

In data 4-1 (English), strategy 5 overstate was applied. In this utterance, speaker said something more than is necessary. In English, Reuben said "How can those guys sleep? There has never been a moment like this before. It's whole new beginning", Reuben wanted to emphasized that at that moment his friend should not slept as they supposed to felt something really great, by saying "It's whole new beginning".

Table 2. Analysis The politeness strategy expressed by the characters in the novel entitled Supernova: K satria, Putri \& Bintang Jatuh translated into English.

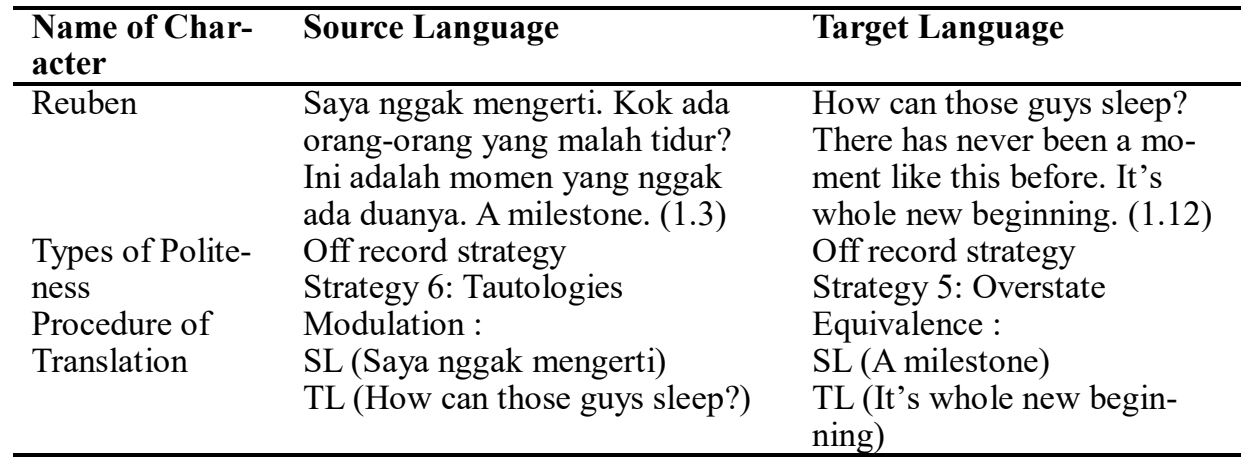


Vol. 3, No. 2, Juli 2019, 54

Available Online at https://ejournal.warmadewa.ac.id/index.php/kulturistik DOI: dx.doi.org/10.22225/kulturistik.3.2.1193

In this second part of the problem, how the politeness strategys expressed by the speakers are analyzed based on the procedure of translation theory from Vinay and Darlbernet (In Hatim and Munday: 2004). In this part of data found two (2) types of procedures used by Reuben in his dialogue. The first procedure is modulation and the second procedure is equivalent.

a. Modulation

Modulation is a variation of the form of message, obtained by a change in the point of view. In the data above, Reuben said "Saya nggak mengerti" in the SL, in a form of declarative. In contrast, in the TL it became, "How can those guys sleep?", in a form of question. Modulation is a variation of form of the message obtained as the result from a shift in the point of view. This change can be justified when the close translation results in a grammatically correct text, but it is considered unsuitable, unidiomatic or awkward in the target language.

In the above data both of the sentences from SL and TL are keeping the same massage but changed the form of the sentence in order to make the translation become more acceptable for readers. It is because, if the SL "Saya tidak mengerti" is directly translated into English, it became "I do not understand", which is not really reflecting the condition when the sentence being uttered. In this context, it is suitable to apply modulation procedure in the TL, "How can those guys sleep?" so that the translation does not feel awkward for the target readers.

b. Equivalent

The other sentence, Reuben also said "A milestone" which is a saying that means a very important moment just happened to him. He really used to use English every time with Dimas as both of them graduated from the US. In the translation version of the novel, the translation used equivalent procedure so that the saying could be more understandable for wider range of target audience.

Table 3. Analysis of The Politeness Differences and How It Is Affect the Translation of The Novel entitled Supernova: Ksatria, Putri \& Bintang Jatuh into English

\begin{tabular}{lll}
\hline $\begin{array}{l}\text { Name of } \\
\text { Character }\end{array}$ & Source Language & Target Language \\
\hline Reuben & Manusia-manusia malang. (5.57) & The miserable wretches. (5.50) \\
$\begin{array}{l}\text { Type of } \\
\text { Politeness }\end{array}$ & Bald on record strategy & Bald on record strategy \\
\hline
\end{tabular}

The translator used the same approach as the author in the above sentence in Reuben dialogue. The main reason of using bald on record strategy could be simply stated in general as whenever S wants to do FTA with a maximum efficiency more than the wants to satisfy H's face, $\mathrm{S}$ will use the bald record strategy.

In Reuben's dialogue above, the translation of "manusia-manusia malang" is translated into "the miserable wretches". The bald on record here conveyed, especially in the choice of word "wretches" as the English translation of "malang" rather than "poor". In the bald record strategy, this is called as nonminimization of the face threat define as maximum efficiency which is very important that there is no redress face is necessary both to speaker or hearer, it would be decrease the urgency of communication. 
Vol. 3, No. 2, Juli 2019, 55

Available Online at https://ejournal.warmadewa.ac.id/index.php/kulturistik DOI: dx.doi.org/10.22225/kulturistik.3.2.1193

The word choice for the translation above is also influenced by the context and also the plot of the novel. Petrey suggested that translation is of course an impossible task. No version of any sentence in one language can possibly capture the semantic richness, phonic structure, syntactic form and connotative allusiveness of a sentence in another language. In regards to that, it is very important to every translator to consider context because there is no such language could always be translated as it is directly into the target language. It is important to consider the context in what kind of situation is the language being used (Petrey, 1984).

In relation to above explanation, the good knowledge that the translator have of both languages culture, custom and norms are also very important impact to the result of the translation. The translator at this point must also able to understand each of the characters in the novel. As for Reuben whose dialogues being discuss in here, captured as a very smart medical doctor and professor who consider science in everything and speaks the truth. At this rate, Reuben could be categorized as someone who follows the objectivism.

Biddle stated that objectivism advocates the virtues of rational self interest - virtues such as independent thinking, productiveness, justice, honesty and self responsibility. This is parallel to the way of the translator transferred the meaning and context of Reuben's dialogue from Bahasa Indonesia to English by considering his character in translating the dialogue (Biddle N, 2012).

\section{CONCLUSION}

The conclusion of this study can be drawn from the analysis of the previous chapter. They are the analysis of The Translation Of Politeness Strategy in Supernova: Ksatria, Putri \& Bintang Jatuh Into Supernova: The Knight, The Princess and The Falling Star. Based on the three formulated research problem, there are three conclusions which can be drawn from this study. First, the result showed that the type of politeness which mostly applied in the dialogue is positive politeness. The positive politeness is mostly applied by both author and translator in the dialogue of the novel. According to Brown and Levinson (1987) in Foley (1997) stated that positive politeness, as expected, seeks to redress the affront to the hearer's positive face (Brown \& Levinson, 1978). Second, based on the procedure of translation theory proposed by Vinay and Dalbernet (in Hatim \& Munday., 2004) showed that the politeness strategys in the dialogue of the novel presented in oblique translation. According to Vinay and Dalbernet (in Hatim \& Munday., 2004), oblique translation is used when a source language text cannot be directly translated without the semantic or lexical changes in a target language text. The procedure of translation applied by the translator in the novel mostly based on situation and cultural background of the novel. The translator also tried to bring the point of view of the target reader to the translation process of the novel so that the results of translation become readable and acceptable to the culture of the target reader. Third, the politeness differences applied in the novel (Bahasa Indonesia and English version) held a very important role in forming and delivering the right messages that wanted to convey by the author to target language. The translator who also played an important role in bridging the message also consider context, and more importantly culture in which belong to the expected target readers. The politeness strategy applied in the dialogue of the novel is not always different but they way it is applied and the language choice require the translator 


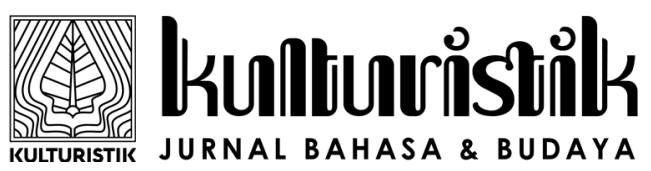

Vol. 3, No. 2, Juli 2019, 56

Available Online at https://ejournal.warmadewa.ac.id/index.php/kulturistik DOI: dx.doi.org/10.22225/kulturistik.3.2.1193

to be more cautious in translating the dialogue to target language.

\section{REFERENCES}

Aveling, H. (2011). Supernova: the Knight, the Princess and the Falling Star. Jakarta: Lontar.

Biddle N. (2012). Indigenous language usage. Canberra, Centre for aboriginal economic policy research school of social sciences. Australia: Australian National University.

Brown, P., \& Levinson, S. C. (1978). Politeness: Some universals in language usage. Cambridge: Cambridge University Press.

Hatim, B., \& Munday., J. (2004). Translation: An advanced resource book. London and New York: Routledge.

Larson, L. M. (1998). Meaning-based Translation. America: United States of America.

Lestari, D. (2001). Supernova; Ksatria, Putri dan Bintang Jatuh. Bandung: Truedee Books.

Margono. (1999). Theory and practice of translation. Denpasar: Fakultas Sastra Universitas Udayana.

Neubert, A. (2000). "Competence in Language, in Languages, and in Translation" in Developing Translation Competence ed. Amsterdam and Philadelphia: John Benjamins.

Petrey, S. (1984). Must History Be Lost in Translation? ”. Translation Perspective, ed. By M.G. Rose, Binghamton: National Resource Center for Translation and Interpretation. 